\title{
Curmudgeons and Dragons? A Content Analysis of the Australian Print Media's Portrayal of the Information Profession 2000 to 2004
}

\author{
L. T. K. ROBINSON \\ Graduate student in Information Studies, \\ Curtin University of Technology, Bentley, Western Australia. \\ Email: Leith.robinson@postgrad.curtin.edu.au
}

\section{ABSTRACT}

The purpose of this study was to determine whether the Australian print media's portrayal of information professionals was different from the real personae of Australian staff. This was tested by content analysis of media images of information personnel in newspapers during the five-year period 2000 to 2004 and subsequent comparison of data to worker profiles and to stereotypes. The findings indicated that the majority of the Australian print media's reporting of the information sphere does not involve the use of clichés, thus contradicting industry opinion and the existing literature on this subject.

\section{Introduction}

Despite recent sweeping changes in the information profession, the worldwide characterisation of librarians, archivists, and records managers remains one of antagonistic (“curmudgeonly") and unfashionable pedants. The problem to be resolved by this study was whether the Australian print media's portrayal of knowledge workers was different from not only the stereotypes but also the actual people. The hypothesis was that the data would support the contention that stereotypical images were common in the nation's print media but that these were inaccurate representations of current employees. The methodology entailed applying content analysis in conjunction with gathering statistics and doing a literature review.

\section{Professional literature and statistics}

Various texts present the argument that the importance of an image arises from its consequences on practitioner status and treatment (Stereotypes of Librarians, n.d.). The literature review showed little evolution in perceptions (much to the chagrin of members of 
the profession), i.e., the historical and the contemporary portrayals were similar. There were certain appearances and attitudes associated with each information professional role. The librarian stereotype was the strongest, portraying librarians as aging white females, often with glasses (Treble, 2003) and colloquially known as “The bun lady.” Archivists and records managers were generally shown as older, Caucasian, and male (Cook, 2002; Roberts, 2002), the stereotype being that of "the absent-minded professor" or "Mr Magoo.” Common to all images was their unattractiveness. Workers were depicted with unfashionable clothing and such unwelcome personality traits as dullness (McQueen, 1995; Brown-Syed \& Sands, 1997), “shushing” (Weaver, 2003), and being overly controlling (Boddington, 2002).

It was found that the fictional renditions of the sex of each branch of the profession were not always borne out in reality. For example, past male librarians have included Assyrian King Ashubanipal (669 to 627 B.C.) and Melvin Dewey, while influential female records and archives theorists include Luciana Duranti and Judith Ellis. Yet the profile of the current Australian information worker was found to match traditional perceptions. The demographics of the stereotypes are statistically accurate as (not withstanding generational change and pluralism) sector members do tend to be female and to be older employees (Davidson, Schwirtlich, \& Smith, 1995; Trundle, 2004; Vital Statistics Report, 2001). Likewise, the profile of an overseas staffer is that of a woman over 40 (Bobrovitz \& Griebel, 2001; Kneale, 2002). Studies of the personalities of archivists and librarians showed that workers are usually rather orderly, but whether they have a quiet disposition is disputed (Pederson, 1999; Ogden, 2003).

\section{Media literature}

The print media's recent reports concerning information staff usually incorporate a comparison with the subject and the myth. As in the professional literature, any noncompliance by a practitioner with the standard image (e.g., age, interests, appearance) was greeted with surprise and was frequently placed in the introductory paragraphs and/or was over-emphasised. The words "not typical” were commonly used. The print media has also used the term "librarian” as an insult, applying it to clothing that is deemed dowdy or prim, e.g., pencil skirts (Givhan, 2004) or to behaviour, e.g., Cricket Australia reprimanding players for speaking publicly (Manthorp, as cited in “Extra Time,” 2003). One should note that different perceptions were presented when the reporting on library and information management was factual, as opposed to mentioning the myth in passing. Items in community 
or local newspapers in particular tended to be promotional (of events) or celebratory (of people, e.g., winning awards) (Excellence in customer service, 2004).

Numerous authors have remarked that stereotypes are often used to ensure audience understanding since they serve as a shortcut to the assimilation of the larger meaning. According to Welch (2003, p. 1), "The combination of a book and a young female librarian in a newspaper photograph is an easily understood message for the majority of readers.” Ericson, Baranek, \& Chan (1987, p. 351) excused media depictions by attributing portrayals to what has been relayed by the source, commenting, "The journalist is left to reproduce the representations the sources have decided to make of themselves." This raises the question of the complicity of library and information science workers in the formation of the myths about their professional image.

Practitioners are divided in their response to their portrayal in the media. Some, such as Andrew (2001), proposed ignoring inaccuracies, and Cram (1997) pointed out that almost all professions have stereotypes, e.g., priests and lawyers. Other information professionals, however, are prompted to counter attack and have termed themselves "image-busters." Their efforts to distance themselves from the stereotypes have given rise to the examination of "the anti-stereotype stereotype.” Unconventional interests and appearance are being paraded on websites and in discussion groups, and calendars (often involving implied and/or actual nudity) are being released such as that of the staff of Camden's [North London] library (Henry \& Walker, 2003).

\section{The design and conduct of the study}

Content analysis is the "systematic analysis of the occurrence of words, phrases and concepts in books, films and other kinds of materials” (Powell, 1997, p. 50). Two newspapers - one national (The Australian - a broadsheet) and one state (The West Australian - a tabloid) — were selected to illustrate if there were any variations in press coverage due to regional focus. The articles were drawn from weekday and weekend editions published in the years 2000 to 2004 . The sources of the clippings varied. The researcher actively accumulated material via newspaper monitoring and also searched the holdings of corporate and academic libraries. Additionally, colleagues and members of the university's faculty offered access to their private collections. (Note: The restriction to certain years and publications was for the purpose of manageability of the undertaking). There was careful selection of a range of print 
media coverage to encompass a mix of issues and events, individual profiles or the profession as a whole, praise and criticism, and large and small stories. The final sample size for this study was 40 articles (see Figure 1) and a pilot study of 10 articles was conducted to test the categories. The pilot study prompted a few changes in questions and layout.

\section{Figure 1: Table of articles}

\begin{tabular}{|c|c|}
\hline $\begin{array}{l}\text { ITEM } \\
\text { NO }\end{array}$ & TITLE OF ARTICLE \\
\hline 1 & “Egalitarian routes to the written word.” The Weekend Australian, 22-23 July 2000, p. 21. \\
\hline 2 & “Charges over art book scam.” The West Australian, 3 August 2000, p. 13. \\
\hline 3 & "Librarians spread the good word.” The West Australian, Today Education, 12 October 2000, p. 7. \\
\hline 4 & “Gates helps libraries.” The Australian, IT, 28 November 2000, p. 46. \\
\hline 5 & “ABC culls its knowledge base.” The Australian, Media, April 26-May 2, 2001, p. 3. \\
\hline 6 & “The paper pusher.” The Australian, Publishing, 6 June 2001, pp. 26-27, 29. \\
\hline 7 & “Revising C.S.Lewis: A cautionary tale.” The Weekend Australian, The Nation, 16-17 June 2001, p. 5. \\
\hline 8 & “Missing files.” The West Australian, 8 February 2002, p. 1. \\
\hline 9 & “Court throws book at reader.” The West Australian, 20 April 2002, p. 4. \\
\hline 10 & “Book recasts her-story of women rights.” The West Australian, The World, 22 April 2002, p. 21. \\
\hline 11 & “Mystery of the missing files.” The West Australian, 11 May 2002, p. 36. \\
\hline 12 & “Cybrary superhero.” The Australian, Higher Education, 22 May 2002, p. 29. \\
\hline 13 & "Tower is one for the record.” The West Australian, 29 May 2002, p. 4. \\
\hline 14 & “Porn sites set to swell literary Pandora’s box.” The West Australian, 4 September 2002, n.p. \\
\hline 15 & “Archives get back lost Kelly papers.” The West Australian, 12 September 2002, p. 34. \\
\hline 16 & “Two page talking book.” The West Australian, Today Dig It, 13 November 2002, p. 10. \\
\hline 17 & “Cocktails at UWA.” The West Australian, U! Out \& About, 12 March 2003, p. 5. \\
\hline 18 & “Fashion for your inner librarian.” The Australian, 25 June 2003, p. 5. \\
\hline 19 & "Why is the Material Girl dressed like a middle-aged librarian?” The West Australian, 16 September 2003, p. 1 \\
\hline 20 & “Madge strikes a prudish pose.” The West Australian, 16 September 2003, p. 9. \\
\hline 21 & “Librarians take us to book.” The West Australian, Letters, 17 September 2003, p. 22. \\
\hline 22 & “Records battle the bulge.” The West Australian, 18 October 2003, p. 15. \\
\hline 23 & “Monks’ view of century preserved.” The West Australian, 12 November 2003, p. 50. \\
\hline 24 & “He said what?” The West Australian, Extra Time, 30 December 2003, p. 63. \\
\hline 25 & “Jump the queue-at a price.” The West Australian, Letters, 24 January 2004, p. 20. \\
\hline 26 & “At your library.” The West Australian, Ed magazine, 10 February 2004, pp.1-6. \\
\hline 27 & “KGB man defected with archive.” The West Australian, Obituaries, 21 February 2004, p. 105. \\
\hline 28 & “Information on the double.” The West Australian, Employment, 3 April 2004, p. 120. \\
\hline 29 & “Book crisis.” The West Australian, Letters, 28 April 2004, p. 19. \\
\hline 30 & “"Money call for library books.” The West Australian, 3 May 2004, p. 15. \\
\hline 31 & “Book crisis.” The West Australian, Letters, 3 May 2004, p. 22. \\
\hline 32 & “Libraries battle to keep up with readers.” The West Australian, 10 May 2004, p. 12. \\
\hline 33 & "Nerdy Jennifer.” The West Australian, Today, 27 July 2004, p. 3. \\
\hline
\end{tabular}




\begin{tabular}{|c|c|}
\hline 34 & “Extending the power and glory of words.” The West Australian, Obituaries, 8 September 2004, p. 72. \\
\hline 35 & "Navigator for info highway.” The Australian, Weekend Careers One, 11-12 September 2004, p.1. \\
\hline 36 & "British library starts a literary and scientific email archive,” The Australian, IT Today, 12 October 2004, p. 34. \\
\hline 37 & “Winter of discontent for Steinbeck’s home town.” The West Australian, World, 7 December 2004, p. 31. \\
\hline 38 & "UWA wins back rare books.” The West Australian, 8 December 2004, p. 4. \\
\hline 39 & “Bereaved Victoria’s silent suffering.” The West Australian, World, 18 December 2004, p. 54. \\
\hline 40 & “Love your library.” The West Australian, Liftout, Excellent Holiday Adventures, 31 December 2004, p. 6. \\
\hline
\end{tabular}

* Note the newspaper repeated the heading for letters to the editor on the same topic but on different days.

The coding framework (or grid) captured the demographic, appearance, and attitudinal characteristics of the print media's presentation of the information profession. This was achieved by the assessment of all aspects of an article, including headlines, text, and accompanying visuals. The coding sheet is provided in Figure 2. 


\section{Coding Sheet}

STUDY:

DATE OF CODING:

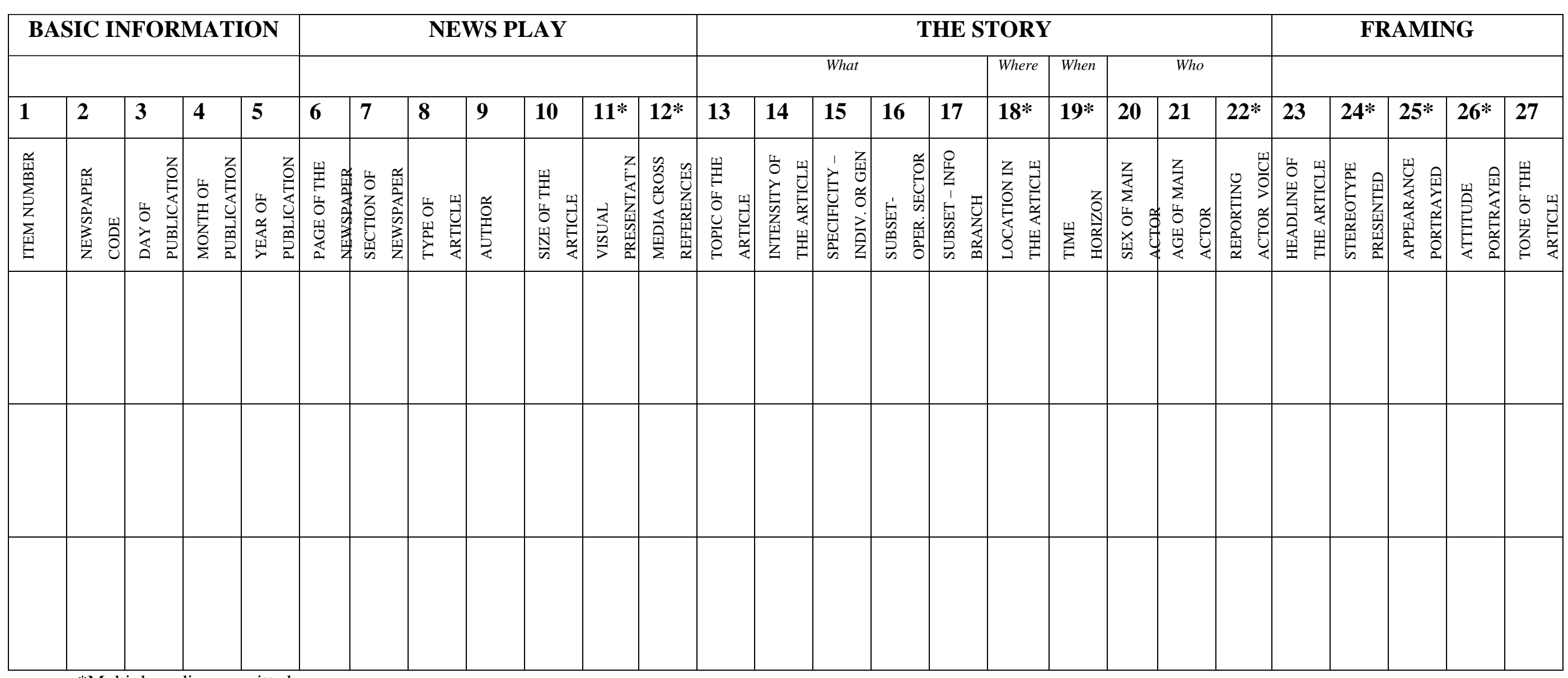

*Multiple coding permitted

Figure 2. Content analysis coding sheet 


\section{The results and analysis}

The investigator was the sole coder, and data extraction and tabulation were performed manually. The demographic data cited in the articles (the story - the who) presented quite a different picture than that of the literature review and conventional thinking within the information sphere. In this study there were 29 cases where the sex of information professionals was reported (Q20, Figure 1), and of these, 16 (55.2\%) were male and 13 (44.8\%) were female. This result counters the notion of men forming only a third of the profession's ranks.

The typical print media article did not report the age of an information employee (Q21, Figure 2). In only four instances (10\%) was a figure provided. Two of the people featured were over 60, and in the other two instances the subjects met the age category of 20 to 39 years. Perhaps the print media are wary of being ageist, or perhaps subjects did not disclose their age. Therefore, this study indicates that Australian print media coverage appears not to be clichéd in a gender or age sense. Although the information professionals portrayed by the print media were mostly Westerners, the gradual growth in the pluralism of Australia’s culture was shown by the number of European surnames of workers.

An information professional practitioner was quoted and/or paraphrased (direct quotes were more common) in $46.81 \%$ of the articles (Q22, Figure 2). This result shows that the information profession sphere has the power to change perceptions since they are not mediated when they appear in print. Knowledge workers also communicate their opinions via print media by responding to stories. Letters to the editor are used for complaints regarding how the profession is depicted or to raise such issues as insufficient funding of libraries. This result also partly exonerates the print media from perpetuating a stereotype and returns to the question of whether practitioners are contributing to clichés regarding the profession.

Due to librarians being the most numerous within the ranks of the profession (ABS, 2001), it was unremarkable that most of the print media articles that specified an information branch referred to libraries (75\%, Q17, Figure 2). Of the others, $12.5 \%$ cited archives, and $7.5 \%$ of the stories involved records centres, while the remaining $5 \%$ of items were on the information sphere generally. The high quantity of reports about the public sector (70\%, Q16, Figure 2) also reflected employment reality (RMAA, 2004). 
The presentation of a complete information profession stereotype (Q24, Figure 2) occurred in only $17.5 \%$ of the articles (or seven of the 40 ) in the sample. Of stories that did use such characters, "the bun lady” was most frequently cited (three times), followed by equal but singular reporting of "the absent-minded professor/Mr Magoo," "the jail warden," "the nerd/neurotic," and "the anti-stereotype stereotype." For instance, the concept of "the jail warden” was raised in "Porn Sites Set to Swell Literary Pandora’s Box” (Item 14, Figure 2). This article detailed the upcoming expansion of the erotica holdings of the National Library of Australia by the commencement of collecting pornographic websites. This section of the catalogue is stored, as the writer described, in "a mysterious steel cabinet . . . kept under lock and key, even to staff,” and can be read only by researchers under supervision.

The lack of the use of stereotypes was a surprise and suggested that perhaps the print media are becoming more careful and less irresponsible in their style than in the past and have themselves recognised that stereotypes are becoming inaccurate as the profession evolves. Yet opposing this reasoning is the finding that greater stereotype use occurred in the mid and latter period of the study. One of the seven instances occurred in 2002, three were in 2003, and two were in 2004. For example, "the absent-minded professor/Mr Magoo" stereotype was used in “Fashion for Your Inner Librarian” (Item 18, Figure 1) to describe the men’s clothing range released in Milan by designer Miuccia Prada.

This study found that most print media articles (82.5\%, Q25, Figure 2—see Figure 3) did not refer to the appearance of information professionals. This result strongly argues that this cliché in journalism is fading, which is in stark contrast to expectations given that the literature review suggested that it was rare when the media did not use stereotypical references, especially in relation to clothing.

\begin{tabular}{|l|c|c|}
\hline OPTION & FREQUENCY & PERCENTAGE \\
\hline None & 33 & $82.5 \%$ \\
\hline Reported (combined total) & 7 & $17.5 \%$ \\
\hline TOTAL & $\mathbf{4 0}$ & $\mathbf{1 0 0 \%}$ \\
\hline \multicolumn{2}{|c|}{ Of the 7 items that did report characteristics, 17 traits were cited. } \\
\hline Female & 2 & $11.76 \%$ \\
\hline Middle-aged or older & 3 & $17.65 \%$ \\
\hline
\end{tabular}




\begin{tabular}{|l|c|c|}
\hline Glasses & 2 & $11.76 \%$ \\
\hline Unfashionable clothing & 5 & $29.40 \%$ \\
\hline Sensible shoes & 2 & $11.76 \%$ \\
\hline Unfashionable hairstyle (esp. bun) & 1 & $5.89 \%$ \\
\hline Stooped/arthritic & 0 & 0 \\
\hline "Way out"/radical & 1 & $5.89 \%$ \\
\hline Everyday/mainstream & 1 & $5.89 \%$ \\
\hline TOTAL & $\mathbf{1 7}$ & $\mathbf{1 0 0 \%}$ \\
\hline
\end{tabular}

Figure 3. Characteristics of appearance of information professionals cited by the print media 2000 to 2004

Only seven of the 40 articles in the sample described a knowledge worker's appearance, and of these seven articles 17 instances were noted. The terms used most often by the print media (and these were matched by the phrases the literature review advised were common) were concerning unfashionable clothing (29.40\%); being middle-aged or older (17.65\%); and being female, having sensible shoes, and wearing glasses (11.76\%). For instance, “Nerdy Jennifer” (Item 33, Figure 1) reported that Hollywood actress Jennifer Garner advised she was an unpopular and awkward child: "I never wore the right clothes and I had a kind of natural geekiness. I was the sort of kid that if you'd asked what I wanted to be, I would have said something like a librarian.”

Yet some of these instances of use were in rebuttal. In over half (four instances), either the information professional involved in the story or a reporter (showing that some of the media have changed their perceptions of the knowledge sector) noted that the stereotypical image had disappeared. Journalist Studdert, “Navigator for Info Highway,” (Item 35, Figure 1) mock-claimed, "There's been a death in the library." She wrote of the old-style librarian (female, glasses, and not to be disturbed) as being “disturbed right out of existence.”

References to attitude or behaviour were the most frequent method of description in this study (present in 62.5\% of articles, Q26, Figure 2-see Figure 4). The higher number of referrals to singular traits (being boring) instead of to a whole character ("the bun lady"—see earlier discussion on caricature citation) at least shows a moderating or lessening of journalistic use of information profession stereotypes. 


\begin{tabular}{|c|c|c|c|}
\hline \multirow{13}{*}{ 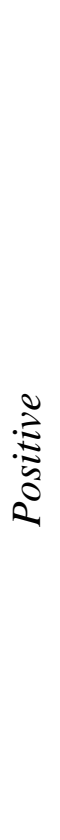 } & OPTION & FREQUENCY & PERCENTAGE \\
\hline & None/neutral & 13 & $27.5 \%$ \\
\hline & Reported (combined total) & 27 & $62.5 \%$ \\
\hline & TOTAL & 40 & $100 \%$ \\
\hline & Of the 27 that did mention & s, 51 characteristi & re cited. \\
\hline & Welcoming/kindly & 2 & $3.92 \%$ \\
\hline & $\begin{array}{l}\text { Astute/knowledgeable/ } \\
\text { organised }\end{array}$ & 7 & $13.73 \%$ \\
\hline & Helpful & 3 & $5.88 \%$ \\
\hline & Innovative/future-focused & 9 & $17.65 \%$ \\
\hline & Dedicated/enthusiastic & 8 & $15.70 \%$ \\
\hline & Essential & 4 & $7.84 \%$ \\
\hline & Interesting & 2 & $3.92 \%$ \\
\hline & SUBTOTAL & 35 & \\
\hline \multirow{11}{*}{ 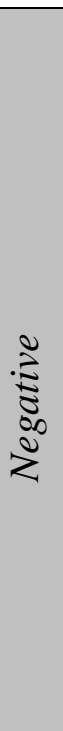 } & Shh!/Hushing/quiet & 3 & $5.88 \%$ \\
\hline & Boring/dull & 2 & $3.92 \%$ \\
\hline & Fussy & 1 & $1.96 \%$ \\
\hline & Prim & 2 & $3.92 \%$ \\
\hline & Forgetful/disorganised & 2 & $3.92 \%$ \\
\hline & Awkward/geeky & 1 & $1.96 \%$ \\
\hline & Hostile/surly & 1 & $1.96 \%$ \\
\hline & Inflexible/ruthless & 0 & 0 \\
\hline & Neglectful/remiss & 4 & $7.84 \%$ \\
\hline & $\begin{array}{l}\text { "Dinosaur"/living in the } \\
\text { past/technophobic }\end{array}$ & 0 & 0 \\
\hline & SUBTOTAL & 16 & \\
\hline & TOTAL & 51 & $100 \%$ \\
\hline
\end{tabular}

Figure 4. Attitudes of information professionals cited by the print media 2000 to 2004

Another finding that may also gladden practitioners is that the most common behaviours cited by the print media were positive. For instance, being innovative and futurefocused was used nine times. The profession as a whole was praised for its use of technology 
by the article “Two Page Talking Book” (Item 16, Figure 1), which explored the developments of formats to aid blind library patrons. Being dedicated and enthusiastic was cited in eight articles, including “ABC Culls Its Knowledge Base,” wherein the ABC's soonto-retire librarian Marjorie Wearne was commended by her colleagues for often working late. The qualities of being astute, knowledgeable, and organised were also frequently reported by the media, appearing seven times.

The highest occurring negative attribute was being neglectful or remiss (four references). For example, the profession as a whole was criticised for sloppy microfilming, whereby parts of pages of then-discarded newspapers were found to have been omitted. The notion of "shh!" or hushing or quietness was cited three times, but two of the three articles advised it was no longer applicable to or enforced by staff. Only the article "Librarians Spread the Good Word” (Item 3, Figure 1) used the term seriously by noting that teacherlibrarians were often quiet achievers.

\section{Conclusions}

This project achieved its three research aims of identifying information personnel stereotypes, assessing their accuracy, and measuring media usage. The clichéd images found in the literature review did match the statistics of the typical Australian practitioner: a middleaged female working in a public library. In contrast, although the print media in the study did refer in the majority of articles to public library staff, many stories concerned younger and male information professionals. This could be attributed to politicking and power issues, such as a belief that men are considered to be more newsworthy, and it may be an attempt to hide the number of women in the profession, perhaps to attract more male workers.

The results of the content analysis of The Australian and The West Australian newspapers are the reverse of what was expected and thus disprove the initial contention that Australian print media were perpetuating information management stereotypes. The framing of a typical article was found not to demean the profession and therefore did not match either the beliefs documented in the literature or those commonly held by those within the information professional sphere. The tone adopted in stories was usually objective, headlines were not overly metaphorical, and traits that were mentioned were more positive than negative. Ultimately, and to answer the research statement, the print media on the whole did 
not present stereotypes or write about elements of clichéd appearance or attitude. Overall, the print media’s approach to reporting on the information profession seems fair.

Whether stereotypes are used affectionately or viciously, however, the results harm the profession. A distinction between the portrayals of different branches of the sector was observed whereby more respect was shown to archivists. This trend has been remarked upon by a number of scholars. Carmichael (as cited in Stereotypes of Librarians, n.d.) suggested the cause was gender-based because of the prominence of women in the ranks of librarianship. Cram (1997) stated that recreational reading (and hence public libraries) were considered less important than archives, which had a preservatory function with collections deemed more significant and with items such as court rulings and government documents.

The question may be asked whether the information profession is or was an easy target given the ingrained stereotypes and the former passivity of practitioners? Perhaps now the sector "fights back" or is vocal when journalistic efforts seem unacceptable, and this may explain the changes that have been observed in print media depictions. Other reasons may be a growing consciousness of the diversity of knowledge staff (perhaps gained through reporters' personal encounters) or simply a result of a reporter not being aware of the information professional stereotypes and hence not applying them

Also, print media operations are evolving and now reflect modern business practices; hence they are sending different messages than in the past. Both the Australian Press Council (2004) and the Australian Journalists Association (2004) have formulated principles and ethics to guide journalistic practices, including warning against the use of stereotypes. Defamation and libel laws also affect reporting, as do the Privacy and Freedom of Information Acts. These statutes are unlikely to be repealed; therefore it is predicted that the reporting trend discovered in this study will continue.

\section{Recommendations}

Content analysis produces data that enables theoretical and/or "hands-on" changes, and the importance of linking research with practice is undeniable. This study could, therefore, be used as a "springboard" to improve the quality of services and benefit the profession. 
$\underline{\text { Recommendations for the information sector }}$

Address the information profession's own perceptions as follows:

1) Change the culture within the field-

Widely circulate these results to heighten self-awareness and to prompt a move away from a culture of blame (such as the criticism of the print media, now shown as largely unfounded) and to prevent complicity in any perpetuation of the stereotype.

2) Counter erroneous perceptions of members, media, and the public-

Practitioners should maintain their efforts to prove that outdated notions are damaging. For example, those workers who are demographically within the stereotype do not necessarily possess the accompanying poor personality with traits such as dullness. Also, Healey (1995) suggested terminology changes to overcome the automatic associations with words such as "librarian.” Proposed alternative position titles include "information specialist” and "resource centre manager."

3) Promote a more positive profile-

Browne (2001) and Welch (2003) wrote of both demonstrating and communicating the profession's dedication to providing information for the enrichment of the community. Osler (as cited in Image Sites, 2001, p. 4) stated, "The librarian of today, and it will be true still more of the librarians of tomorrow, are not fiery dragons interposed between the people and the books. They are useful public servants, who manage libraries in the interest of the public.” It should be emphasised that the transformations are to the advantage of patrons. If information staff are friendly and centres are welcoming, visitor enjoyment will be heightened.

\section{4) Tackle potential labour shortages-}

The predominance of older workers in Australia illustrates the need for concentrated succession planning. Indeed, most of the developed world's information sector is ageing, and Teece (2004) praised the proactive approach adopted by the United States, which includes recruitment programs supported by First Lady Laura Bush, herself a former librarian. 
Recommendations for the media sector

Although the print media's reporting was found in this study to be (on the whole) positive, the recommendations are:

1) continue fairness and accuracy in the depiction of the information profession,

2) highlight achievements by knowledge centres and staff,

3) reduce references to stereotypes and clichés (especially in headlines), and

4) acknowledge the contribution of the information sector to the community.

A cautious stance has been adopted in relation to the findings. It is acknowledged that the non-use of stereotypes by the print media has been demonstrated in this study but that other projects (with other samples of papers and years) may produce different data. The material discovered for the literature review was often dated prior to the print media sample, so the contrast of the findings to what was expected could in part be due to time. But there are many opportunities for future studies to build upon what has been achieved and outlined in this work. Potential projects could include a replication of this study using two different Australian newspapers, an expansion to sampling articles from all the national and state capital dailies, or a broadening of the scope to other mediums such as Australian television and cinematic depictions.

\section{References}

ALIA core values statement. (2002). Retrieved March 10, 2005, from http://www.alia.org.au/policies/core.values.html

Andrew, A.R. (2001). The image of the librarian visited. Retrieved January 3, 2004, from http://conferences.alia.org.au/shllc2001/papers.andrew.html

Archives Society of Alberta. (2002). Newsletter Winter/Spring 2002. Retrieved January 18, 2004, from http://www.archivesalberta.org/spr02/cook.htm

Association for Education in Journalism and Mass Communication. (2004). Masters abstracts. Retrieved December 5, 2004, from http://www.aejmc.org/abstracts/masters 
Australian Bureau of Statistics. (2001). AusStats 8561.0 public libraries, Australia. Retrieved December 25, 2003, from http://www.abs.gov.au/ausstas/abs@nsf

Australian Journalists Association Code of Ethics. (2004). Retrieved February 21, 2005, from http://www.australian-news.net/codethics.htm

Australian Press Council Statement of Principles. (2004). Retrieved February 21, 2005, from http://www.presscouncil.org.au/pcsite/complaints/sop.html

Bauer, M., Ragnarsdottir, A., Rudolfsdottir, A., \& Durant, J. (1995). Public perceptions of BSE and CJD risk in Europe [project report]. Science and technology in the British press, 1946-1990: A systematic content analysis of the press. Retrieved July 31, 2004, from http://www.academic.csuohio.edu

Bobrovitz, J., \& Griebel, R. (2001). If the (sensible) shoe fits: The image of the librarian. Retrieved January 3, 2004, from http://www.sla.org/chapter/cwcn/wwest/v4n4/jbimage.htm

Boddington, A. (2002, Winter). Archives in crisis. Oxfordshire History Local News, 95, 1-2.

Brown-Syed, C., \& Sands, C. (1997). Librarians in fiction: A discussion. Retrieved January 1, 2004, from http://www.valinor.ca/el3.htm

Browne, M. (2000). Everything old is new again. Retrieved January 26, 2004, from http://www.alia.org.au/publishing/incite/2000/03/frotnline.html

Busha, C.H., \& Harter, S.P. (1980). Research methods in librarianship: Techniques and interpretation. New York: Academic Press.

Cram, J. (1997). Self love and joy and satisfaction in librarianship. Retrieved January 11, 2004, from http://www.alia.org.au/ jcram/self-Love.html 
Davidson, J., Schwirtlich, A., \& Smith, B. (1995). The Australian Society of Archivists membership survey. Archives and Manuscripts, 23(2), 306-321.

Dilevko, J., \& Gottlieb, L. (2004). The portrayal of librarians in obituaries at the end of the twentieth century. Library Quarterly, 74(2), 152-180.

Engle, M. (1998). Remythologizing work: The role of archetypal images in the humanization of librarianship. Retrieved January 24, 2004, from http://www.library.cornell.edu/olinuris/ref/staff/moe/archetype.html

Ericson, R. V., Baranek, P. M., \& Chan, J.B.L. (1987). Visualizing deviance: A study of news organization. Toronto: University of Toronto Press, 345-364.

Events. (2004, October). Incite, 25, 32.

Excellence in workforce. (2004, August 31). Stirling Times, 11.

Extra time. (2003, December 30). The West Australian, 63.

Givhan, R. (2004, April 14). From the catwalk-At the office. The West Australian, 3

GTN Coding Manual 4. (2003). Retrieved January 1, 2005, from http://www.gradethenews.org/pages/reportcard/coding\%20manual.pdf

Healey, K. (Ed.). (1995). An Australian identity. Balmain, NSW: The Spinney Press.

Henry, J., \& Walker, T. (2003). Librarians strip off their dust jackets for charity calendar. Retrieved January 4, 2004, from http://www.telegraph.co.uk/news/main

Hicks, S. (2004, January 29). Re: Dec-Jan issue of “In the mailbox.” Aus-archivists mailing list. Retrieved January 29, 2004 from e-mail aus-archivists@archivists.org.au. 
Hughes, R. (1995). The culture of complaint: The fraying of America. London: Harvill, 3-69.

Image sites. (2001). Retrieved January 10, 2004, from http://www.newbreedlibrarian.org.archives/01.01.feb2001/feature2.html

Jones, R. (2002). From the country lane to the information super highway and back again: A lapsed transport geographer's perspective on paradigm shifts and longitudinal rural research. In P. Holland, F. Stephenson, \& A. Wearing (Eds.), 2001, Geography, a spatial odyssey: Proceedings of the New Zealand Geographical Society and Institute of Australian Geographers Joint Conference. The New Zealand Geographical Society.

Kneale, R. (2002). You don't look like a librarian! Librarians' views of public perception in the internet age. Retrieved May 30, 2004, from http://www.librarianimage.net/perc.html

Macintyre, S., \& Clark, A. (2003). The history wars. Melbourne: Melbourne University Press, 191-215.

McQueen, H. (1995). Perceptions of archives and archivists. Proceedings of the 1995 Australian Society of Archivists Inc. Conference, $27^{\text {th }}-29^{\text {th }}$ July, 1995. Canberra: ASA Inc.

Milivojevic, S. (2003). Media monitoring manual. Retrieved January 11, 2005, from http://www.media-diversity.org/PDFS/Media Monitoring Manual.pdf

Moen, W. (1997). The role of content analysis in evaluation metadata for the U.S. Government Information Locator Service (GILS): Results from an exploratory study. Retrieved April 10, 2004, from http://www.unt.edu.wmoen/publications/GILSMDContentAnalysis.htm

Ogden, A. (2003). What are librarians really like? Retrieved January 10, 2004, from http://www.slais.ubc.ca/courses/libr500/02-03-wt1/www/A_Ogden/like.htm 
Pederson, A. (1999). Understanding ourselves \& others: Australian archivists \& temperament. Proceedings of the 1999 Australian Society of Archivists Inc. Conference, 1999. Canberra: ASA Inc.

Pemberton, J. M. (1996). High (professional) anxiety? Image and status in records management. Records Management Quarterly, 30(1), 66-68, 70-73.

Piggott, M. (2002). Unearthing hidden dusty archival treasures. Bulletin of the University of Melbourne Archives, 11, 1-2.

Powell, R. (1997). Basic research methods for librarians (3rd ed.). Norwood: NJ: Ablex.

Records Management Association of Australasia. (1998). By-law no. 1 code of ethics. St Helens, Tas: Author.

RMAA Informaa WA Newsletter. (2004, November-December).

Roberts, D. (2002, August). Archivists . . like librarians only weirder. Vital Signs, 2, 2.

Rochester, M. (1995). Library and information science research in Australia 1985-1994: A content analysis of research articles in the Australian Library Journal and Australian Academic and Research Libraries. Australian Academic and Research Libraries, 26(3), 163-170.

Sitton, S., Terry, R., \& Key, J. (2001). A content analysis of Oklahoma's two largest newspapers' 1998 coverage of Oklahoma swine concentrated animal feeding operations. Retrieved December 5, 2004, from http://www.agnews.tamu.edu/saas/sitton2001.htm

Stereotypes of librarians. (n.d.). Retrieved December 26, 2003, from http://home.earthlink.net/ cyberresearcher/stereotypes.htm

Teece, P. (2004). America shows the way on ageing workforce. Incite, 25, 52. 
The Australian: Titles. (2005). Retrieved March 13, 2005, from http://newsmedianet.com.au/home/titles/title

Treble, J. (2003, October). Reflections from a water trough. Quill, 103(3).

Trundle, I. (2004, June). Ms. Survey average speaks. Incite, 25,24.

Vital statistics: Western Australian cultural statistics (An information consultancy for the Ministry for Culture and the Arts). (2001). Retrieved January 26, 2005, from http://www.cultureandarts.wa.gov.au/

Weaver, E. (2003). The belly-dancing librarian. Retrieved August 19, 2004, from http://www.sonic.net/ erisw/bdlib.html

Welch, L. (2003). Thinking beyond the bun. Retrieved January 26, 2004, from http://www.alia.org.au/members-only/groups/aliasa/interalia/2003.4/thinking.html 